\title{
Dairy Products Marketing Systems and its Constraints in Gimbi District, West Wollega Zone, Oromia, Ethiopia
}

\section{Amanuel Bekuma*, Ulfina Galmessa and Lemma Fita}

College of Agriculture and Veterinary Science, Ambo University, Ambo, Ethiopia

"Corresponding author: Amanuel Bekuma, College of Agriculture and Veterinary Science, Ambo University, Ambo, Ethiopia, Tel: +251-910-178476; E-mail: amanuelbekuma11@gmail.com

Received date: July 09, 2018; Accepted date: August 27, 2018; Published date: September 07, 2018

Copyright: $\odot 2018$ Bekuma A, et al. This is an open-access article distributed under the terms of the Creative Commons Attribution License, which permits unrestricted use, distribution, and reproduction in any medium, provided the original author and source are credited.

\begin{abstract}
The study was conducted in Gimbi district, West Wollega zone to characterize dairy products marketing systems and to determine and prioritize common dairy products marketing constraints. 130 household respondents were selected based on ownership of dairy cows and dairy products marketing potential and viability. Accordingly, traditionally processed butter, whole milk and fermented whole milk are marketable dairy products, of which butter is the major dairy product sold by farmers. From the result, only informal dairy products marketing system through different channels were practiced. Low milk quantity, distance to the markets, high cost of transport and spoilage were the major constraints of dairy products marketing systems in the study area. As market is the driving force to the development of this sector, responsible stakeholders should not only work towards dairy production and productivity of cattle but also towards dairy marketing options.
\end{abstract}

Keywords: Constraints; Dairy products; Gimbi district; Marketing

\section{Introduction}

Most dairy farmers in Ethiopia are widely dispersed in rural areas while majority of dairy markets are in urban areas. Due to highly perishable nature of dairy products and its potential to transmit zoonotic disease and other pathogens and toxins, it is difficult for dairy farmers to exchange in urban markets. Thus, a whole chain approach is basically needed, which includes education of consumers [4].

Unless milk and milk products find a market outlet, they are retained for household consumption and the level of production is kept low [7]. This low level of production together with the general decline in the local production over the years as a result of the fast-growing population, have led to an increase in import dependence in dairy products.

Marketing of dairy products, therefore, requires as much emphasis as for the production of milk. Biological interventions to improve the nutritional and health status of dairy animal may not bring about the desired improvements of income to the producers unless viable markets absorb the produce. Lack of market can mean wastage of the milk, and the resources that went in to its production (labor, land, time).

As Tsehay [15] stated, provision of improved and sustainable milk marketing arrangements in smallholder villages is, therefore, indispensable for advancement of the national dairy industry. An effective milk- marketing net work benefits both producers and consumers, and through its linkages with related sectors, the national economy as a whole [3].

Despite its substantial roles, little has been known so far about the role of dairy products marketing in the study area. On the other hand, evaluation of the prevailing dairy products marketing systems and identification of its constraints would assist to design appropriate improvement strategies. Such a study is limited for dairy products marketing systems of West Wollega and particularly unavailable for the study area. Therefore, this study was carried-out to characterize dairy products marketing systems and identify and prioritize major constraints and suggest appropriate area of intervention for improvement of the sector.

\section{Materials and Methods}

\section{Description of the study area}

Gimbi district is located at about $441 \mathrm{~km}$ away from Addis Ababa, the capital city of the country to the west. Geographically the district is located $9^{\circ} 10^{\circ}-9^{\circ} 17^{\circ}$ North latitude and $35^{\circ} 44^{\circ}-36^{\circ} 09^{\circ}$ East longitudes; covering a land area of 100,965 hectare $\left(1009.65 \mathrm{~km}^{2}\right)$. The area has one long rainy season extending from March to mid-October with annual rainfall ranging from $1400-1800 \mathrm{ml}$. The mean minimum and maximum annual temperature ranges between $10^{\circ} \mathrm{C}$ and $30^{\circ} \mathrm{C}$ and the elevation of the study area ranges from $1200 \mathrm{~m}-2222 \mathrm{~m}$ a.s.l. Mixed crop-livestock agriculture is the main stay in the area. Like to many parts of Ethiopia, the study area is endowed with significant number of domestic animals; 93,640 cattle, 46,115 sheep, 7,207 goats, 131 mule and 80,370 poultry [5].

\section{Sampling method}

The study district was purposively selected due to high demand for milk and milk products and the socio-economy of the society was highly relying on crop-livestock production and marketing [9]. For this study, both purposive and random sampling techniques were employed. Out of the total district's kebeles, top ten dairy cattle production kebeles were purposively selected. Out of the top ten kebeles, based on dairy products marketing potential and viability four kebeles were randomly selected. The target sampling population has been defined as all households in the randomly selected kebeles that own milking cows and practicing dairy products marketing. In order to select household respondents, simple random sampling technique 
having two stage procedures was used. In the first stage, households having milking cows of any breed and size and practicing marketing of dairy products have been identified and listed in respective kebeles. In the second stage, individual milking cow owner households and practicing marketing of dairy products were randomly selected from the list for an interview.

The sample size for collecting quantitative data for this study was determined by using Yemane formula:

$$
\mathrm{n}=\mathrm{N} / 1+\mathrm{N}(\mathrm{e})^{2}
$$

Where: $\mathrm{n}$-designates the sample size the researcher uses;

$\mathrm{N}$-Total households owning milking cows and practicing dairy products marketing;

e-Level of precision or margin of error $8 \%$ (0.08).

1-designates the probability of the event occurring

During the study period, about 770 households in the randomly selected kebeles own milking cows of any breed and size and practicing dairy products marketing.

Thus, $\mathrm{n}=770 /\left(1+770 \times(0.08)^{2}\right), \mathrm{n}=130$, which is the determined sample size for the study.

\section{Data collection}

Data was collected from both primary and secondary sources. The primary sources were obtained through a semi-structured questionnaire; it was pre-tested the questionnaire before the actual data collection was carried out so as to evaluate the appropriateness of clarity of the questions, and interpretation of the questions by the farmers and time required for an interview. The feedback from the pretest was used to implement for the final questions. The interviews were conducted by trained research assistants under close supervision by the researcher while the secondary data were collected from different sources such as books, research publications, journals, office reports of zonal and district agriculture etc.

\section{Method of data analyses}

The nature of the research was cross sectional with survey method and therefore, triangulation methods, i.e., quantitative, qualitative and observation were employed. Qualitative data derived from direct observations was examined and presented in the form of discussions. Descriptive statistics like frequency distributions and percentage were employed for quantitative analysis. The arranged data was analyzed using SPSS software version 20; and the results were presented using tables, graphs and in rank.

\section{Results and Discussion}

\section{Dairy products marketing}

Milk producers in the study area not only consume milk products, but also sell the surplus milk and butter to consumers and retailers. Traditionally processed butter, whole milk and fermented whole milk are marketable dairy products, of which butter is the major dairy product sold by farmers. The income gained from the sale of milk products is used to purchase farm inputs like feed, fertilizer and improved crop varieties as well as food and non-food items like education materials for their children. The study result depicted that milk and milk products in the study area were found to be marketed through informal marketing system. The current result agreed to Eyassu and Asaminew [6,14].

\section{Milk marketing systems}

Though dairy products in Ethiopia are channeled to consumers through both formal and informal dairy markets $[1,12]$, respondents reported that there was no formal marketing channel for milk and milk byproducts in the study area. Dairy owners as a result sell their milk and milk products informally to unlicensed vendors, retailers or village consumers. Few producers located near to urban areas sold their milk and milk products informally to cafeteria, tea houses and direct to consumers. Informal market involves direct delivery of fresh milk by producers to consumers in the immediate neighborhood and sale to itinerant traders or individuals in nearby towns.

In the study are, there are two types of milk selling systems: contractual agreement and irregular system. The former system was a type of a monthly contractual agreement that means the producer and his/her client agreed on the amount to be delivered in a day and the price per litter as well and finally the producer received the money at the end of the month. This means that price is usually set through negotiation between the producer (seller) and the buyer. And the producers which were selling the milk in such type of agreement were those producers who owned the crossbred cows and more number of indigenous lactating cows.

The second system was that the producer directly sells to the consumer. This type of market was on-and-off type; it is not sustainable. It existed in the time when there was peak production in wet season and the mode of payment is cash in hand. Because of limited rural road network; the absence of collection systems and processing facilities and organized dairy cooperatives, the flow of liquid milk from surplus milk producing dairy farmers to urban centers is impended. In the study area, milk price was fluctuating in the dry and wet seasons which were ranging from Ethiopian birr (ETB) 12-16 per liter.

Out of the total respondents, about $76.15 \%$ of producers were those who do not sell the raw/fresh milk due to low milk production. They use the milk for household consumption only. And about $17.69 \%$ and $6.15 \%$ respondents indicated that they sell fresh milk to consumers and traders, respectively (Figure 1). In contrast to the current study, 30.83\% and $12.78 \%$ of households in the study areas of Chencha and Kucha districts respectively explained that they sell fresh milk [11]. 


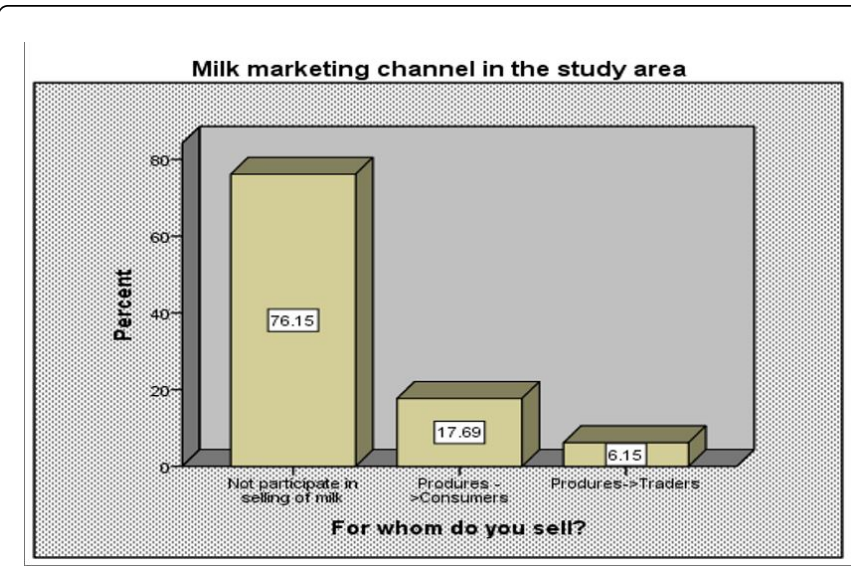

Figure 1: Graphical representations of milk sellers in the study area.

\section{Milk marketing channels}

In Ethiopia, milk and milk products marketing is not yet developed, the possible reason for low marketable outlet of dairy products were due to producers and consumers were spatially separated; most producers were found in the rural areas while consumers or profitable market is found in urban areas. Most of the milk supply is distributed from producer to consumer through informal marketing channels in both rural and urban areas. This, in turn, reduces incentives to participate in economic transactions and results in subsistence rather than market-oriented production systems [2].

From this study, different butter and milk market participants were identified in marketing functions between producer and the final consumer. Milk producers and consumers were key participants in the milk market. The private milk collecting, and processing plants are missing in the Zone in general and in the study district in particular. The survey results also identified two types of milk marketing channels. These are:

- Producer $\rightarrow$ Consumer: About $17.69 \%$ of the producers sell their milk directly to consumers in the study area and it is the predominant milk marketing channel (Figure 1). In this milk marketing channel, the milk producer delivers the morning and evening raw/fresh milk for the individual consumers. Consumers are the individuals who were directly buying the raw milk from the producers. A few consumers were giving the comments about the taste of milk they are provided with for the milk providers.

- Producer $\rightarrow$ trader (cafeteria, tea kiosks): Only about $6.15 \%$ (Figure 1) of the milk producers sell their products to traders in the study area. The greater number of indigenous and crossbred lactating cows the farmers own, the more they were participated in this channel. As indicated in the result of the study, cooperative marketing is not existing in the study area, the main problems for that was due to small quantities of dairy products produced per farmers, seasonal fluctuations in supplies, poor and seasonally impressive roads, low level of education about collection, handling and preservation of quality milk and poor service of concerning bodies.

However, dairy cooperatives are important to farmers in reducing transportation cost and save time. Cooperatives are also vital to give producers a guaranteed access to marker and sell their milk. So, establishment of milk cooperatives can give dairy farmers a broader choice of marketing their milk instead of depending on local traders and neighborhood buyers. In dissimilar to the results of current study, [8] study from the areas of Mid Rift Valley of Ethiopia who reported that $71.3,59.2,21,3.3$ and $2.2 \%$ of respondents sold their dairy products to local market, home, dairy cooperatives, shop and cafeteria, respectively.

\section{Butter marketing}

Butter in study area was produced in traditional system. And it was supplied to the market after the woman collected the butter produced from 1-3 churnings. About 7-8 litres of the average volume of fermented milk were required for one churning process and the average volume of fresh whole milk required to produce a kilogram of butter was $16.02 \pm 1.56$ liters. In the study area, butter prices were fluctuating in the dry and wet seasons, in holydays and festivals period and non-fasting condition, which were ranging from ETB 50.00 for a kilogram in the wet season to about ETB 70.00- 80.00 for a kilogram in the dry season at farmer level. Retail prices ranged between ETB 135.00 to 150.00 , depending on product quality and market demand. The reason for having such variation of marketing price of dairy products (butter and milk) due selling time might be to the fact that as it was discussed with butter traders, the farmers in wet season they have sufficient amount of forage for their dairy animals. Thus, the cattle would give better milk production for dairy products processing (yogurt, butter, cheese, etc.) in turn the marketing price being low. In similar case, in fasting period some people are abstaining from animal origin food consumption for certain period of time as result the price decreases. However, in holidays and festivals periods and no fasting periods more people are consuming dairy products so that the marketing price increases while in dry season the farmers are usually challenging feed shortage for their cattle. Thus, dairy products become low in production at the hand of farmers and market level.

The trends of butter price increases from one occasion to the other point in time due to different factors such as inflation effects, urbanization and income increasing in the country. For example, the price of butter observed in the current study is significantly higher than that reported by Negash et al. who indicated an average price of butter 15.4 and $27.78 \mathrm{Birr} / \mathrm{kg}$ for the rainy and dry seasons, respectively in eastern Wollega western Ethiopia [13]. The current result also slightly disagree with the findings by Tola who reported an average price of butter 134.79 in Birr/kg for dry and wet season in selected districts of Wolaita Zone Southern Ethiopia [14].

According to respondents, the sale price of milk and milk products was not consistent across years it was varying due to the effect of season, holiday and festivals, fasting and no fasting condition in the study area. As revealed from Table 1 the respondents had multiple reasons for the cause of increasing demand of milk and milk products, of which the combination of due to dry season, holiday and festivals and fasting (52.3\%); dry season and no fasting (20.8\%) and only dry season $(11.5 \%)$ were the major one.

\begin{tabular}{|l|l|l|l|}
\hline $\begin{array}{l}\text { At what time do demand of milk and milk } \\
\text { products increase }\end{array}$ & $\mathbf{N}$ & $\%$ & Rank \\
\hline Dry period & 15 & 11.5 & 3 rd \\
\hline Non-fasting period & 2 & 1.5 & 7 th \\
\hline Holidays and festivals & 4 & 3.1 & 5 th \\
\hline
\end{tabular}


Page 4 of 5

\begin{tabular}{|l|l|l|l|}
\hline Dry and wet seasons and holiday and festivals & 3 & 2.3 & 6 th \\
\hline Dry and wet season & 4 & 3.1 & 5 th \\
\hline Dry season and non-fasting & 27 & 20.8 & 2nd \\
\hline None fasting period and fasting & 5 & 3.8 & 4 th \\
\hline Dry season holiday and festivals and fasting & 68 & 52.3 & 1st \\
\hline Dry season, none fasting period and fasting period & 2 & 1.5 & 7 th \\
\hline
\end{tabular}

- In this channel retailers buy butter from the market and sell in the same market to make some profit. As the reports of respondents in the study district only $10 \%$ (Figure 3 ) of butter market participants sell their butter by this channel and the reported mode of payment for butter purchase was cash payment in hand and no other modes of payment for butter purchase.

- $\quad$ Producer $\rightarrow$ Small traders $\rightarrow$ big traders: this butter channel is only carried out in Gimbi town.

Table 1: Factors that affect milk and milk products demand and price. $\mathrm{N}=$ number of respondents.

In the present study area, the price of butter and milk is reaching its peak during the big social festivals, no fasting periods and dry period (Bona) season when the economic activities become high and its lean during fasting period and summer (Ganna) season when economic activities become low.

\section{Butter marketing channels}

The participants of butter market channels in study district were the producers, small traders, retailers and the consumers (Figure 2). The producers were bringing the butter to the market places in the market days by walking for a few hours to three and above hours travel. The market places are Bikilal, Geba senbeta, Tole, Gambela and Gimbi town. The producers were selling the butter to small traders, the retailers and consumers. The retailer sells butter to small traders and consumer in the district. The small traders were taking butter to Gimbi town and sell for big traders and/or consumers.

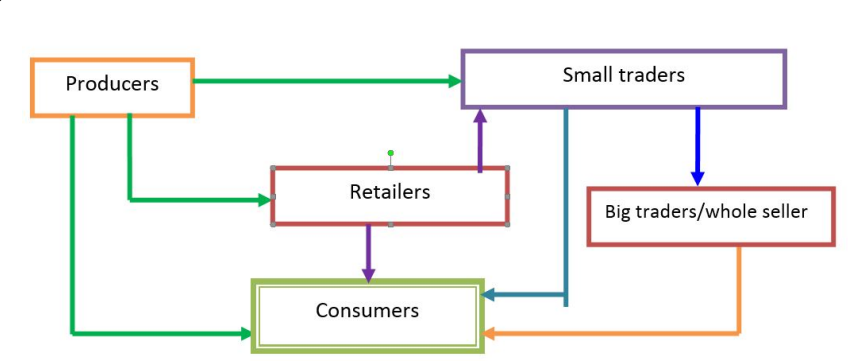

Figure 2: Market channels of butter in the study area.

The major butter marketing channels identified during the study period are:

- Producer $\rightarrow$ Consumer: This channel is found to involve the direct sale of butter to

- consumers in the nearby village home and local market places and is the predominant $(63.1 \%)$ butter marketing channel in the study area (Figure 3). The channel was the shortest in terms of intermediaries and smallest in terms of volume of butter and value. Those consumers who usually purchase butter for cosmetics rather than cooking butter are categorized in this channel. Butter for consumption is mostly purchased in markets where there is better supply of butter in terms of quality and quantity with ample bargaining alternatives.

- Producer $\rightarrow$ Retailer $\rightarrow$ Consumer: This channel is especially exercised at Gambela and Bikilal locally available markets.

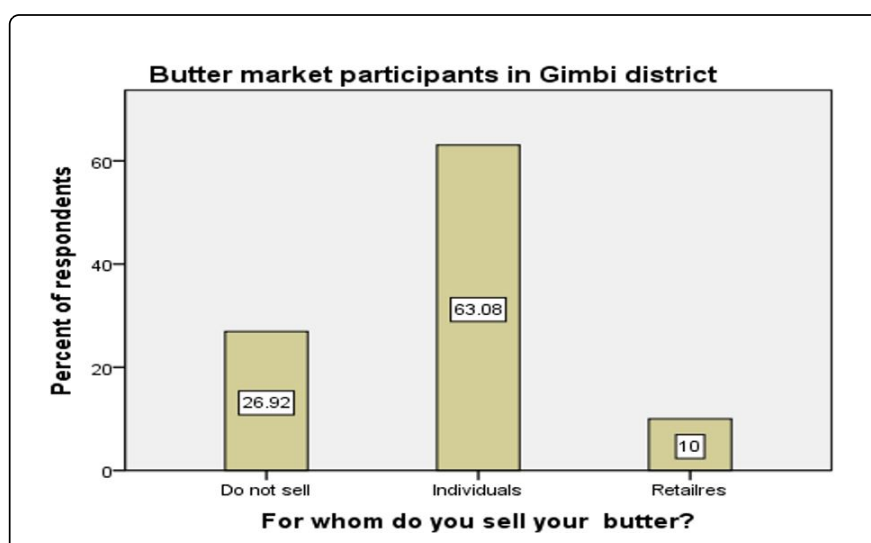

Figure 3: Butter market participants in Gimbi district.

\section{Dairy products marketing constraints}

The dairy products marketing system in the study area face severe constraints. As shown in Table 2, the major constraints for dairy products marketing identified by the producers were low amount of milk produced (75.4\%), long distance to market (10.8\%) and high cost of transport $(7.7 \%)$. Cultural taboo is indicated as a limiting factor for milk marketing by only $3.1 \%$ of the respondents. This result is contrary to the report of Tegegne in east Showa zone of Oromia, that among the many reasons reported by farmers, insufficient amount of milk production and cultural restriction were the most common hindering factors [10].

\begin{tabular}{|l|l|l|l|l|l|l|l|l|l|l|}
\hline & \multicolumn{2}{|l|}{$\begin{array}{l}\text { Less } \\
\text { milk } \\
\text { quantity }\end{array}$} & \multicolumn{2}{|l|}{$\begin{array}{l}\text { Distance } \\
\text { to market }\end{array}$} & \multicolumn{2}{l|}{$\begin{array}{l}\text { Cultural } \\
\text { taboo }\end{array}$} & \multicolumn{2}{l|}{$\begin{array}{l}\text { High cost } \\
\text { of } \\
\text { transport }\end{array}$} & \multicolumn{2}{|l|}{ Spoilage } \\
\hline Rural kebeles & $\mathbf{N}$ & $\%$ & $\mathbf{N}$ & $\%$ & $\mathrm{~N}$ & $\%$ & $\mathrm{~N}$ & $\%$ & $\mathrm{~N}$ & $\%$ \\
\hline $\begin{array}{l}\text { Chuta } \\
\text { Giyorgisi }\end{array}$ & 20 & 77 & 1 & 3.8 & 2 & 7.69 & 1 & 3.85 & 2 & 7.69 \\
\hline Lelisa Yesus & 27 & 90 & 2 & 6.67 & 0 & 0 & 1 & 3.33 & 0 & 0 \\
\hline $\begin{array}{l}\text { Bikiltu } \\
\text { Tokuma }\end{array}$ & 28 & 80 & 7 & 20 & 1 & 2.86 & 2 & 5.71 & 1 & 2.86 \\
\hline $\begin{array}{l}\text { Enango } \\
\text { Dembali }\end{array}$ & 23 & 59 & 4 & 10.26 & 1 & 2.56 & 6 & 15.38 & 1 & 2.56 \\
\hline Total & 98 & 75.4 & 14 & 10.77 & 4 & 3.08 & 10 & 7.69 & 4 & 3.08 \\
\hline
\end{tabular}

Table 2: Reasons for non-participation in milk marketing in study area. $\mathrm{N}=$ number of respondents. 
Citation: Bekuma A, Galmessa U, Fita L (2018) Dairy Products Marketing Systems and its Constraints in Gimbi District, West Wollega Zone, Oromia, Ethiopia. J Vet Sci Technol 9: 556. doi:10.4172/2157-7579.1000556

Page 5 of 5

\section{Conclusion and Recommendation}

This study revealed that dairy products are marketed informally via different channels and mainly hampered by many constraints. Low amount of milk produced, distance to the market and high cost of transport was the major among the constraints. As market is the driving force to the development of this sector and provision of improved and sustainable milk marketing arrangements in smallholder villages is indispensable for advancement of the national dairy industry, responsible stakeholders should not only work towards dairy production and productivity of cattle but also towards dairy marketing options.

\section{Acknowledgements}

We would like to acknowledge Ambo University and Gimbi District Livestock and Fishery Resources Development Office for their permission and support to carry out this research. The study communities are duly acknowledged for sharing their knowledge.

\section{References}

1. Berhnau K (2012) Market Access and Value Chain Analysis of Dairy Industry in Ethiopia: The Case of Wolaita Zone. Haramaya University, Ethiopia.

2. Fekadu B (1994) Present situation and future aspects of milk production, milk handling and processing of dairy products in Southern Ethiopia. Agricultural University of Norway, Norway.

3. Tsehay R (2002) Small-scale milk marketing and processing in Ethiopia. In: Smallholder dairy production and market opportunity and constraints. Proceeding of south workshop held at NDDB, Anand, India, and 13-16 March 2001. NDDB (National Dairy Development Board), Anand, India, and ILRI (International Livestock Research Institute), Nairobi, Kenya, pp: 352-367.

4. Berhane M, Workneh A (2003) Promotion of dairy marketing using farmer's cooperatives: Lessons from India. In: Jobre Y, Gebru G (eds). Challenges and opportunities of livestock marketing in Ethiopia. Proceedings of the 10th annual conference of ESAP (Ethiopian Society of
Animal Production) held in Addis Ababa, Ethiopia, 22-24 August 2002. ESAP, Addis Ababa, Ethiopia, pp: 81-87.

5. CSAGW (2016) Central Statistical Agency of Gimbi Woreda, Ethiopia.

6. Gimbi District Livestock and Fishery Resources Development Office (2016).

7. Seifu E, Tassew A (2014) Small-scale milk processing, utilization and marketing of traditional dairy products in Bahir Dar Zuria and Mecha districts, northwestern Ethiopia. Journal of Food Technology Research 1: 122-132.

8. Tsegay L, Gebreegziabher Z (2015) Marketing of dairy products in selected districts of Wolaita zone, Southern Ethiopia. Journal of Marketing and Consumer Research 14: 140-147.

9. Ahmed MA, Ehui S, Assefa Y (2003) Dairy development in Ethiopia. Intl Food Policy Res Inst 123.

10. Tegegne A, Gebremedhin B, Hoekstra D, Belay B, Mekasha Y (2013) Smallholder dairy production and marketing systems in Ethiopia: IPMS experiences and opportunities for market-oriented development.

11. Minale G, Yilkal T (2015) Dairy production, processing and marketing in Chencha and Kutcha Districts, Southern Ethiopia. Journal of Marketing and Consumer Research 9: 13-14.

12. Belete A, Azage T, Fekadu B, Berhanu G (2010) Cattle milk and meat production and marketing systems and opportunities for marketorientation in Fogera woreda, Amhara region, Ethiopia. IPMS (Improving Productivity and Market Success) of Ethiopian Farmers Project Working Paper 19. ILRI (International Livestock Research Institute), Nairobi, Kenya 19: 65.

13. Negash F, Tadesse E, Aseffa E, Yimamu C, Hundessa F (2012) Production, handling, processing, utilization and marketing of milk in the Mid Rift Valley of Ethiopia. Livestock Research for Rural Development 24.

14. Tola A (2002) Traditional milk and milk products handling practices and raw milk quality in eastern Wollega. Alemaya University, Alemaya, Ethiopia.

15. Fita L, Beyene F, Hegde PB (2005) Traditional Milk and Milk products Handling Practices and Preservation Methods in three Districts of East Shoa Zone of Oromia. ESAP Proceedings 185.

16. Yamane T (1967) Statistics, an Introductory Analysis. 2nd edn. Harper and Row, New York, USA 1: 122-132. 